\title{
Insects of the Subfamily Scolytinae (Insecta: Coleoptera, Curculionidae) Collected with Pitfall and Ethanol Traps in Primary Forests of Central Amazonia
}

\author{
Raimunda Liege Souza de Abreu, Greicilany de Araújo Ribeiro, \\ Bazilio Frasco Vianez, and Ceci Sales-Campos \\ Department of Forest Products, National Institute for Amazon Research, Av. André Araújo, 2936. 69060-001 Manaus, AM, Brazil \\ Correspondence should be addressed to Raimunda Liege Souza de Abreu, raiabreu@inpa.gov.br
}

Received 30 September 2011; Revised 28 November 2011; Accepted 29 November 2011

Academic Editor: David G. James

Copyright () 2012 Raimunda Liege Souza de Abreu et al. This is an open access article distributed under the Creative Commons Attribution License, which permits unrestricted use, distribution, and reproduction in any medium, provided the original work is properly cited.

\begin{abstract}
An experiment was conducted in a primary forest area of the Tropical Forest Experimental Station, $45 \mathrm{~km}$ from Manaus-Boa Vista Highway, in order to compare the insect fauna of the subfamily Scolytinae, in flight activity and on the ground. Five impact traps of the type Escolitideo/Curitiba, with ethanol baits, were installed at the height of $3 \mathrm{~m}$ above the ground, and five pitfall traps were buried in the same area of the above ground traps. The data collections were evaluated through abundance, richness, and Simpson diversity index, and, to compare these data with the pitfalls and the months collection, the ANOVA was used. The Pearson correlation test was also carried out to evaluate the meteorological factors (temperature and rainfall). From the total of 2,910 Scolytinae, 2,341 were captured in pitfall traps representing $80.45 \%$ and 569 with Escolitideo/Curitiba traps representing $19.55 \%$. The most abundant species in the collections were Xyleborus volvulus Fabricius and Xyleborus affinis Eichhoff, and this was classified as constant in both habitats. The result of the analysis indicates that the Simpson's index was high and that the abundance of insects was affected by the types of trap and by the month of collection. The analysis of correlation with meteorological factors showed that only Xyleborus spinulosus species presented significant correlation with temperature.
\end{abstract}

\section{Introduction}

The Scolytinae are mostly secondary predators by developing under natural conditions in trees injured, hit by lightning, fire, plants nutritionally deficient, drooping, and so forth, but can attack healthy plants also [1]. This subfamily presents species phyllophagous (bark beetles), which feed on the phloem tissues, that is, the inner part of the bark of the tree, and xylomycetophagous (beetles of ambrosia) which have as their main food symbiotic fungi, which introduce and cultivate in the host plant [2-4]. The beetles xylomycetophagous attack preferably sapwood which is richer in nutrients, but in some species of wood, the attack also happens in the heartwood [5].

The Scolytinae attack usually begins within twenty-four hours after the tree is cut and each forest species has greater or lesser resistance, but none is totally free of infestation by these insects. The resistance presented by each species is probably related to the attractive substances and the wood hardness which undoubtedly influences the speed of penetration and the general importance of the attack.

These insects have been captured in various regions of the world. In the Amazon region they were also found attacking several hosts, such as forest and fruit trees, as shown in some studies carried out by Mendes [6], Abreu and Dietrich [7], Abreu [8], Abreu and Bandeira [9], Barbosa [10], Dall'Oglio and Peres-Filho [11], and Matias and Abreu [12].

Studies involving biology and ecology of this subfamily have also been conducted in the Amazon, using mainly flight intercept traps, in which an attractive substance is used [1315]. These insects have also been found in other substrates, as shown by surveys conducted by Schubart and Beck [16], Penny and Arias [13], Morais [17, 18], and Rodrigues [19], in samples collected from trees, leaf litter and on the ground, 
where various types of traps were used, including the pitfall trap. Therefore, the capture of these insects on the ground and in flight activity is important for the complete knowledge of their life cycle, and at the same time, to know if the species caught in flight are the same found on the ground.

\section{Material and Methods}

This work was carried out with beetles of the subfamily Scolytinae collected in the Tropical Forestry Station, $45 \mathrm{~km}$ from Manaus, on the BR-174 highway, with an area of 21,000 ha and geographical coordinates $02^{\circ} 35^{\prime} 55.5^{\prime \prime}$ South and $60^{\circ} 02^{\prime} 14.8^{\prime \prime}$ West of Greenwich. In this area the average minimum annual temperature is $20^{\circ} \mathrm{C}$ and the maximum $26^{\circ} \mathrm{C}$, with an average relative air humidity of $77 \%$ [20]. The soil of the region is clayey, and it can be classified as Oxisol and Ultisol [21].

Five modified impact traps of the type Escolitídeo/ Curitiba (EC) were used for this survey, using 100\% commercial alcohol as attraction [22], for the capture of the insects in flight, and five pitfall traps for capture of those with activity on the ground. The collection period happened from July 2005 to July 2006.

The impact trap consists of a conical cover, a panel of impact, a funnel, and a bottle for collection, containing alcohol 30\% with detergent. The bait is placed inside a glass bottle attached to the panel with a pierced cap to allow volatilization. The traps were installed at a height of $3 \mathrm{~m}$ above the ground, and with, the aid of a nylon rope, they were tied to two trees at a distance of $30 \mathrm{~m}$ from each other (Figure 1(a)).

The pitfall trap consists of a $500 \mathrm{~mL}$ glass bottle, an acrylic sheet, $25 \mathrm{~cm} \times 25 \mathrm{~cm}$, and four PVC tubes with $40 \mathrm{~cm}$ in length. During the assembly, the bottles were buried, leaving the openings at the ground level to allow the insects to fall inside them. Picric acid at $0.003 \%$ concentration, which is considered neutral, that is, does not attract or repel the insects, was used to preserve the insects. The acrylic sheets were used as coverage, which were supported by four PVC tubes, buried to half of their lengths (Figure 1(b)).

The samples were collected weekly, when the renewal of the bait and liquid preservatives were made. The collected beetles were identified by means of direct comparison with specimens of the Invertebrate Collection of the National Institute for Amazon Research. Taxonomic identification keys were also used [1,23-28].

The faunistic analysis was obtained through absolute and relative abundance, constancy, species richness, and the calculation of the Simpson diversity index referring to each month of collection. Absolute abundance was done by direct count of the individuals and the relative abundance, by the calculations of the percentages of individuals of each species in relation to the total number of captured individuals [29]. The constancy was determined by the percentage of occurrence of the species in the collections. According to the obtained percentages, the species were separated into the following categories: (a) constant species (W) present in more than $50 \%$ of the collections, (b) accessory species (Y) present in 25 to $50 \%$ of the collections; (c) accidental species

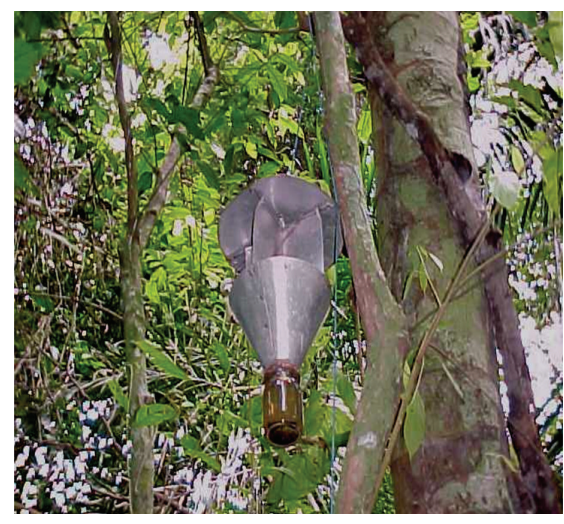

(a)

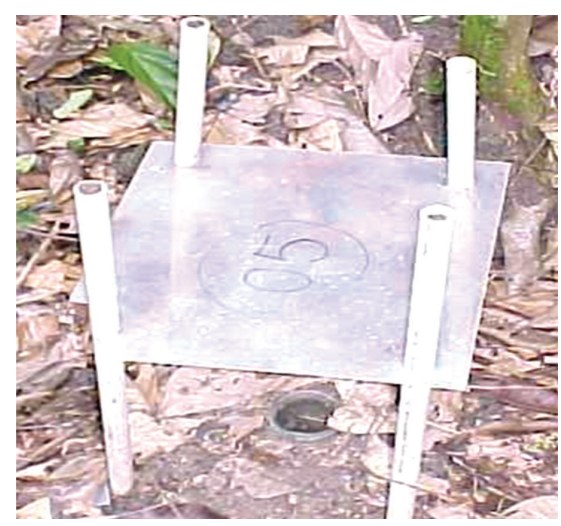

(b)

Figure 1: Traps used to capture insects. (a) Escolitídeo/Curitiba trap-EC and (b) Pitfall trap.

(Z) in less than $25 \%$ of the collections [30]. The Simpson diversity index was calculated according to the formula: $D=$ $1-\sum\left(n_{i}\left(n_{i}-1\right) / N(N-1)\right)$, where $n$ is the number of sampled individuals for each $i$ species and $N$ is the total number of sampled individuals.

The analysis of abundance, the Simpson's index, and the richness of the species as a function of the type of trap and the months of collection was done by ANOVA. For these analyses data were transformed into $\log (x+1)$, and the significance level was $P<0.01$. The monthly fluctuation analysis of the four most abundant species was also carried out, relating the number of collected insects in each type of trap with the data of temperature and rainfall by Pearson Correlation [31].

\section{Results and Discussion}

According to the data shown in Tables 1 and 2, 2,910 Scolytinae specimens were captured, from which 2,341 with the pitfall trap, representing $80.45 \%$ and 569 with the EC trap, representing, $19.55 \%$. The data show the existence of nine genera and 26 species. The Xyleborus genus stood out from the others because it represented $97 \%$ of the collection in the pitfall trap and $57.14 \%$ in the EC trap. The predominance of this genus has already been observed in the work carried out also in primary forest by Abreu [14].

From all the species captured with the pitfall trap, the ones that stood out are the species Xyleborus volvulus 
Fabricius, representing 50.11\% (1,173 individuals.); Xyleborus affinis Eichhoff, with $38.02 \%$ (890 individuals); Xyleborus ferrugineus Fabricius with 4.36\% (102 individuals); Xyleborus spinulosus Blandford, with 4.06\% (95 individuals). The others represented $3.46 \%$ (81 individuals). In the EC trap, X. affinis represented 34.62\% (197 individuals); X. volvulus, with $18.28 \%$ (104 individuals); Premnobius cavipennis Eichhoff, with $11.6 \%$ (66 individuals); Hypothenemus eruditus Westwood, with 9.67\% (55 individuals); H. obscurus (Fabricius) with $5.98 \%$ (34 individuals). The remaining accounted for $19.85 \%$ (113 individuals) (Tables 1 and 2).

Quantitatively there was some numerical superiority for the pitfall trap because it was responsible for almost $90 \%$ of the collected specimens, but, in richness, there was some advantage for the EC trap. While this trap was responsible for the capture of 25 species, the pitfall trap captured only 13. From the studied species, $X$. affinis, $X$. volvulus, $X$. ferrugineus, X. spinulosus, Theoborus solitariceps, X. flavus, P. cavipennis, H. obscurus, H. eruditus, Monarthrum sp. 2, Amphicranus sp. 1 and Coccotrypes palmarum were captured with the two traps (Tables 1 and 2).

In relation to the analysis of richness, abundance, and the Simpson's index, the results indicate that the of Simpson's index $\left(R^{2}=0.098 ; F_{11,96}=0.953 ; P=0.4939\right)$ was not affected neither by the type of trap, nor by the month. On the other hand, the abundance $\left(R^{2}=0.4361 ; F_{11,96}=6.75\right.$; $P<0.001)$ is related to the month of collection, and the type of trap and richness $\left(R^{2}=0.337 ; F_{11,96}=4,436 ; P<0.001\right)$ is only affected by the month of collection. The result of these indexes for each sampled point and month of collection is represented in Tables 3 and 4 .

The greatest abundance of species in pitfall traps was recorded in the months of August and November 2005 and May 2006, while, in the EC trap, it was in the months of January and July 2006. In the analysis of richness with the EC trap, the largest and smallest numbers of species were registered in the months of October and December 2005, respectively. For the pitfall trap, that happened in the months of August and July 2005.

In general, the Simpson diversity index was high, reflecting less diversity and the dominance of two species, $X$. volvulus and $X$. affinis. For the EC trap, this index varied from 0.12 (trap 4, January 2006) to 1 (traps 2, 3, and 5, December 2005). For the pitfall trap, it varied from 0.170 (trap 3, March 2006) to 1 (trap 1, July 2005; trap 5, March 2006; trap 5, July 2006; trap 1, 3, 5, July 2006).

Regarding the constancy, in the pitfall trap, three species have been considered constant, two accessory and 6 accidental. In the EC trap, three species have been considered constant, five accessory and 16 accidental. It was also observed that the $X$. affinis species was constant for the two traps, becoming evident the importance of this species in the studied environment.

The analysis of correlation of the number of insects with rainfall and temperature indicates that only the $X$. spinulosus species was affected by the temperature $(r=0.443$; $P=0.039)$, since the number of individuals increased as a function of the temperature. Although the temperature is considered one of the most important climatic factors in the

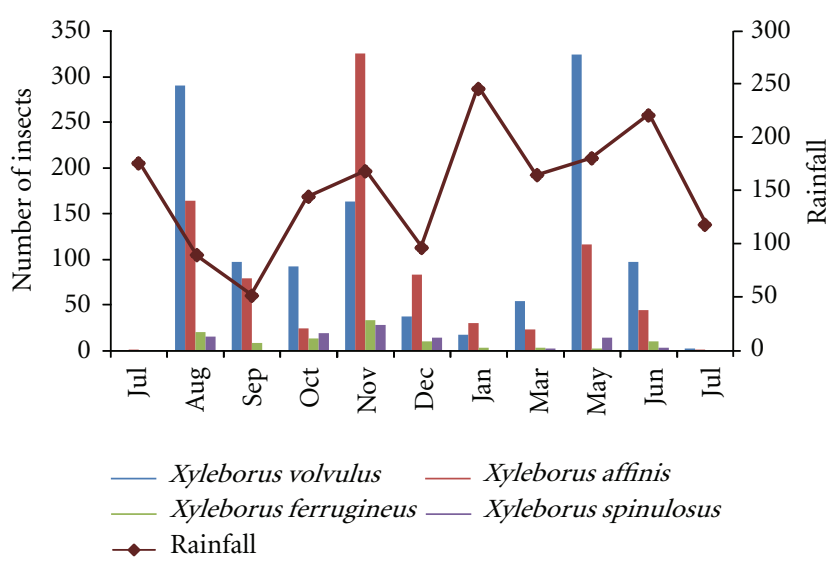

FIGURE 2: Monthly rainfall and total number of four of the most abundant species of Scolytinae subfamily collected with pitfall traps from July 2005 to July 2006, in primary forest of Central Amazon.

development and survival of the beetles of the Scolytinae subfamily, it tends to be higher in the microclimate of the host, but less prone to sudden fluctuations in the external environment $[1,32]$. This was observed in the course of this work and probably that is why this factor did not influence the activity of these beetles on external environment, that is, in flight activity and on the ground.

Data from insects collected with pitfall traps and Escolitideo/Curitiba traps relating rainfall and temperature with the number of insects of the four most abundant species are represented in Figures 2, 3, 4, and 5. In these figures it can be observed that for the pitfall trap, the species $X$. affinis, and $X$. volvulus presented a population peak in August and November 2005 and May 2006. It can also be noticed that in the EC trap, $X$. affinis presented peaks in January, May and June 2006, while $X$. volvulus presented a peak only in July 2006. The months of August 2005 and July 2006 showed low values of rainfall, while, in November 2005 and May 2006 these values were high.

When analyzing the rainfall data some studies suggest that this factor influences on the population and the behavior of the Scolytinae, observing that high values of precipitation affect the abundance of these insects $[32,33]$. Other authors presented the opposite, as shown in a study carried out by Flechtmann et al. [34], where the capture peak of Scolytinae coincides with high intensity of rainfall.

In this context and based on the outcome of this work, it can be affirmed that temperature and precipitation did not affect the activity of most of these insects, both in flight and on the ground. These results agree with Hulcr et al. [35] claiming that circumtropical species, like $X$. affinis and $X$. volvulus, are usually not affected by climatic factors, since they are found in rainy and dry weather.

In this work it has been observed that, despite the 25 species captured with the EC trap using alcohol as attraction, the number of specimens is considered small if compared to the pitfall trap. In forest plantations in Brazil with a single forest species, the capture of these insects using this kind of attraction has been more efficient [22, 36-38]. In a primary or secondary forest, the substrate is very rich, due to 
TABLE 1: Absolute and relative abundance of insects of the subfamily Scolytinae collected with pitfall traps during the period of July 2005 to July 2006, in primary forest of Central Amazon.

\begin{tabular}{|c|c|c|c|c|c|c|c|c|c|c|c|c|c|c|c|}
\hline \multirow{2}{*}{ Species } & \multicolumn{15}{|c|}{ Months } \\
\hline & Jul & Aug & Sep & Oct & Nov & Dec & Jan & Feb & Mar & Apr & May & Jun & Jul & Total & $\%$ \\
\hline Xyleborus volvulus & 0 & 290 & 97 & 92 & 163 & 37 & 17 & 0 & 54 & 0 & 324 & 97 & 2 & 1173 & 50.11 \\
\hline Xyleborus affinis & 1 & 164 & 79 & 24 & 325 & 83 & 30 & 0 & 23 & 0 & 116 & 44 & 1 & 890 & 38.02 \\
\hline Xyleborus ferrugineus & 0 & 20 & 8 & 13 & 33 & 10 & 3 & 0 & 3 & 0 & 2 & 10 & 0 & 102 & 4.36 \\
\hline Xyleborus spinulosus & 0 & 15 & 0 & 19 & 28 & 14 & 0 & 0 & 2 & 0 & 14 & 3 & 0 & 95 & 4.06 \\
\hline Theoborus solitariceps & 0 & 4 & 0 & 0 & 18 & 0 & 0 & 0 & 0 & 0 & 0 & 0 & 0 & 22 & 0.94 \\
\hline Xylosandrus compactus & 0 & 2 & 0 & 3 & 4 & 3 & 4 & 0 & 2 & 0 & 0 & 0 & 1 & 19 & 0.81 \\
\hline Xyleborus flavus & 0 & 0 & 0 & 0 & 0 & 12 & 0 & 0 & 0 & 0 & 0 & 0 & 1 & 13 & 0.56 \\
\hline Coccotrypes palmarum & 2 & 0 & 1 & 0 & 0 & 0 & 4 & 0 & 0 & 0 & 3 & 0 & 0 & 10 & 0.43 \\
\hline Amphicranus sp. 1 & 2 & 1 & 4 & 2 & 0 & 0 & 0 & 0 & 0 & 0 & 0 & 0 & 0 & 9 & 0.38 \\
\hline Premnobius cavipennis & 0 & 2 & 0 & 0 & 0 & 0 & 0 & 0 & 0 & 0 & 0 & 1 & 1 & 4 & 0.17 \\
\hline Hypothenemus obscurus & 0 & 1 & 1 & 0 & 0 & 0 & 0 & 0 & 0 & 0 & 0 & 0 & 0 & 2 & 0.09 \\
\hline Hypothenemus eruditus & 1 & 0 & 0 & 0 & 0 & 0 & 0 & 0 & 0 & 0 & 0 & 0 & 0 & 1 & 0.04 \\
\hline Monarthrum sp. 2 & 0 & 0 & 0 & 1 & 0 & 0 & 0 & 0 & 0 & 0 & 0 & 0 & 0 & 1 & 0.04 \\
\hline TOTAL & 6 & 499 & 190 & 154 & 571 & 159 & 58 & 0 & 84 & 0 & 459 & 155 & 6 & 2341 & 100 \\
\hline
\end{tabular}

TABLE 2: Absolute and relative abundance of insects of the subfamily Scolytinae collected with Escolitídeo/Curitiba traps during the period of July 2005 to July 2006, in primary forest of Central Amazon.

\begin{tabular}{|c|c|c|c|c|c|c|c|c|c|c|c|c|c|c|c|}
\hline \multirow{2}{*}{ Species } & \multicolumn{15}{|c|}{ Months } \\
\hline & Jul & Aug & Sep & Oct & Nov & Dec & Jan & Feb & Mar & Apr & May & Jun & Jul & Total & $\%$ \\
\hline Xyleborus affinis & 10 & 17 & 7 & 8 & 9 & 1 & 55 & 0 & 15 & 0 & 35 & 28 & 12 & 197 & 34.62 \\
\hline Xyleborus volvulus & 0 & 0 & 1 & 2 & 0 & 0 & 3 & 0 & 0 & 0 & 0 & 5 & 93 & 104 & 18.28 \\
\hline Premnobius cavipennis & 2 & 5 & 13 & 7 & 4 & 1 & 4 & 0 & 6 & 0 & 16 & 6 & 2 & 66 & 11.60 \\
\hline Hypothenemus eruditus & 1 & 1 & 3 & 2 & 3 & 0 & 1 & 0 & 2 & 0 & 7 & 9 & 26 & 55 & 9.67 \\
\hline Hypothenemus obscurus & 1 & 3 & 8 & 4 & 3 & 0 & 0 & 0 & 0 & 0 & 10 & 2 & 3 & 34 & 5.98 \\
\hline Monarthrum durum & 0 & 0 & 1 & 1 & 4 & 2 & 6 & 0 & 1 & 0 & 6 & 8 & 0 & 29 & 5.10 \\
\hline Sampsonius dampfi & 0 & 0 & 5 & 3 & 2 & 0 & 0 & 0 & 0 & 0 & 6 & 0 & 0 & 16 & 2.81 \\
\hline Sampsonius prolongatus & 0 & 0 & 0 & 2 & 1 & 0 & 6 & 0 & 2 & 0 & 2 & 0 & 0 & 13 & 2.28 \\
\hline Xyleborus spinulosus & 0 & 1 & 0 & 1 & 3 & 0 & 3 & 0 & 0 & 0 & 0 & 0 & 3 & 11 & 1.93 \\
\hline Xyleborus ferrugineus & 0 & 0 & 0 & 0 & 6 & 0 & 0 & 0 & 1 & 0 & 1 & 1 & 1 & 10 & 1.76 \\
\hline Sampsonius detractus & 0 & 1 & 1 & 0 & 2 & 0 & 2 & 0 & 0 & 0 & 2 & 0 & 0 & 8 & 1.41 \\
\hline Coccotrypes palmarum & 0 & 0 & 0 & 0 & 0 & 1 & 0 & 0 & 0 & 0 & 0 & 4 & 0 & 5 & 0.88 \\
\hline Amphicranus sp. 1 & 0 & 0 & 0 & 1 & 0 & 1 & 0 & 0 & 1 & 0 & 1 & 0 & 0 & 4 & 0.70 \\
\hline Theoborus solitariceps & 0 & 2 & 0 & 1 & 1 & 0 & 0 & 0 & 0 & 0 & 0 & 0 & 0 & 4 & 0.70 \\
\hline $\begin{array}{l}\text { Monarthrum } \\
\text { semipaleans }\end{array}$ & 0 & 2 & 0 & 0 & 0 & 0 & 0 & 0 & 0 & 0 & 0 & 0 & 0 & 2 & 0.35 \\
\hline Sampsonius pedrosai & 0 & 0 & 1 & 0 & 0 & 0 & 1 & 0 & 0 & 0 & 0 & 0 & 0 & 2 & 0.35 \\
\hline Xyleborus flavus & 0 & 1 & 0 & 0 & 0 & 0 & 0 & 0 & 0 & 0 & 0 & 0 & 0 & 1 & 0.18 \\
\hline Xyleborus solitarinus & 0 & 0 & 0 & 1 & 0 & 0 & 0 & 0 & 0 & 0 & 0 & 0 & 0 & 1 & 0.18 \\
\hline Hypothenemus sp. 1 & 1 & 0 & 0 & 0 & 0 & 0 & 0 & 0 & 0 & 0 & 0 & 0 & 0 & 1 & 0.18 \\
\hline Sampsonuis giganteus & 0 & 0 & 0 & 1 & 0 & 0 & 0 & 0 & 0 & 0 & 0 & 0 & 0 & 1 & 0.18 \\
\hline $\begin{array}{l}\text { Cryptocarenus } \\
\text { diadematus }\end{array}$ & 0 & 1 & 0 & 0 & 0 & 0 & 0 & 0 & 0 & 0 & 0 & 0 & 0 & 1 & 0.18 \\
\hline Cryptocarenus seriatus & 0 & 1 & 0 & 0 & 0 & 0 & 0 & 0 & 0 & 0 & 0 & 0 & 0 & 1 & 0.18 \\
\hline Cryptocarenus heveae & 0 & 1 & 0 & 0 & 0 & 0 & 0 & 0 & 0 & 0 & 0 & 0 & 0 & 1 & 0.18 \\
\hline Monarthrum sp. 1 & 0 & 0 & 1 & 0 & 0 & 0 & 0 & 0 & 0 & 0 & 0 & 0 & 0 & 1 & 0.18 \\
\hline Monarthrum sp. 2 & 0 & 0 & 1 & 0 & 0 & 0 & 0 & 0 & 0 & 0 & 0 & 0 & 0 & 1 & 0.18 \\
\hline TOTAL & 15 & 36 & 42 & 34 & 38 & 6 & 81 & 0 & 28 & 0 & 86 & 63 & 140 & 569 & 100 \\
\hline
\end{tabular}




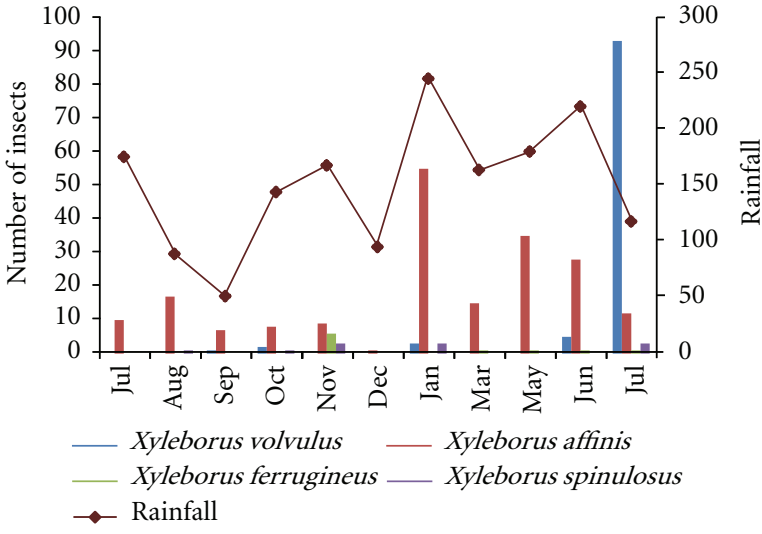

Figure 3: Monthly rainfall and total number of four of the most abundant species of Scolytinae subfamily collected with Escolitídeo/Curitiba traps from July 2005 to July 2006, in primary forest of Central Amazon.

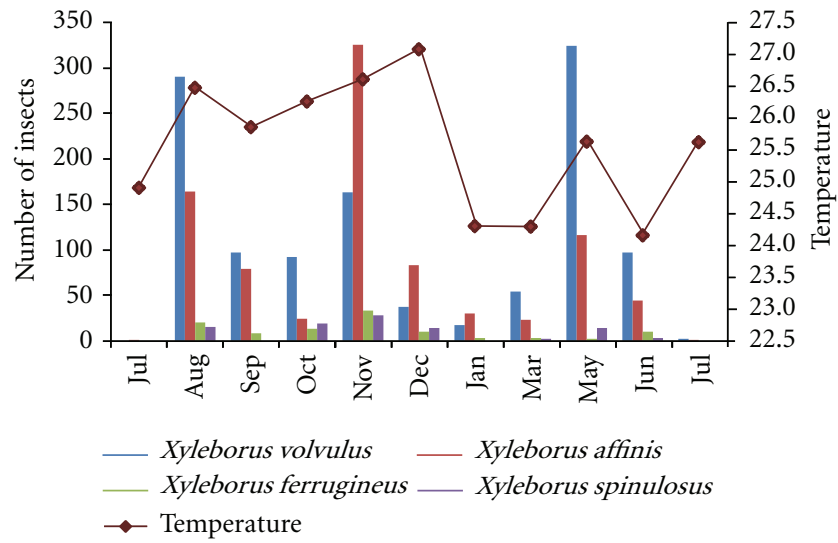

Figure 4: Monthly temperature and total number of four of the most abundant species of Scolytinae subfamily collected with pitfall traps from July 2005 to July 2006, in primary forest of Central Amazon.

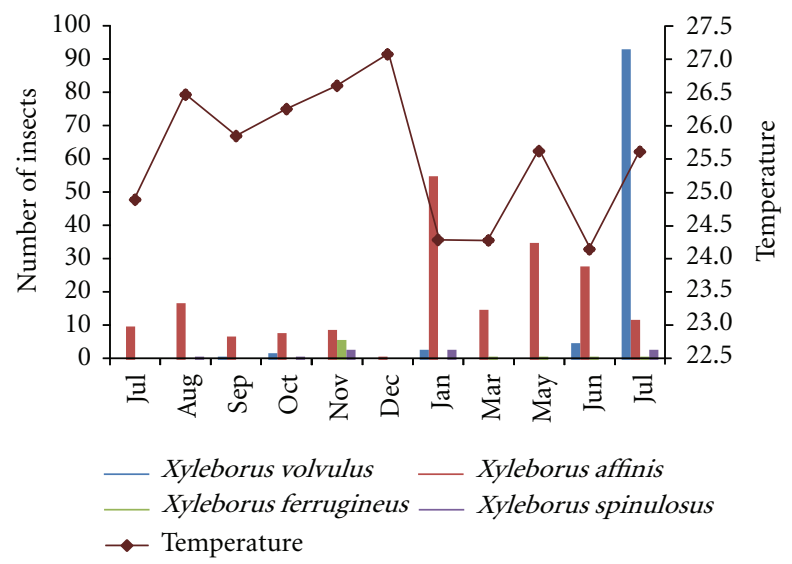

Figure 5: Monthly temperature and total number of four of the most abundant species of Scolytinae subfamily collected with Escolitídeo/Curitiba traps from July 2005 to July 2006, in primary forest of Central Amazon.
Table 3: Abundance, richness, and Simpson index of the species collected with five pitfall traps from July 2005 to July 2006.

(a)

\begin{tabular}{|c|c|c|c|}
\hline \multicolumn{4}{|c|}{2005} \\
\hline Month & Abundance & Richness & Simpson \\
\hline \multirow{5}{*}{ Jul } & 0 & 0 & 1 \\
\hline & 2 & 1 & 0 \\
\hline & 10 & 3 & 0,46 \\
\hline & 0 & 0 & 1 \\
\hline & 0 & 0 & 1 \\
\hline \multirow{5}{*}{ Aug } & 118 & 6 & 0,589 \\
\hline & 102 & 4 & 0,470 \\
\hline & 84 & 4 & 0,596 \\
\hline & 95 & 6 & 0,618 \\
\hline & 104 & 6 & 0,433 \\
\hline \multirow{5}{*}{ Sep } & 3 & 3 & 0,667 \\
\hline & 8 & 3 & 0,594 \\
\hline & 45 & 4 & 0,593 \\
\hline & 59 & 3 & 0,561 \\
\hline & 75 & 2 & 0,461 \\
\hline \multirow{5}{*}{ Oct } & 36 & 5 & 0,690 \\
\hline & 32 & 5 & 0,375 \\
\hline & 18 & 3 & 0,494 \\
\hline & 36 & 4 & 0,437 \\
\hline & 32 & 4 & 0,689 \\
\hline \multirow{5}{*}{ Nov } & 218 & 6 & 0,526 \\
\hline & 102 & 4 & 0,552 \\
\hline & 72 & 5 & 0,588 \\
\hline & 108 & 4 & 0,573 \\
\hline & 71 & 4 & 0,492 \\
\hline \multirow{5}{*}{ Dec } & 65 & 5 & 0,455 \\
\hline & 33 & 5 & 0,571 \\
\hline & 22 & 4 & 0,479 \\
\hline & 27 & 5 & 0,694 \\
\hline & 12 & 4 & 0,681 \\
\hline
\end{tabular}

(b)

\begin{tabular}{lccc}
\hline \multirow{3}{*}{ Month } & \multicolumn{2}{c}{2006} & \\
& Abundance & Richness & Simpson \\
\multirow{3}{*}{ Jan } & 7 & 1 & 0 \\
& 15 & 4 & 0,516 \\
& 11 & 3 & 0,562 \\
& 2 & 2 & 0,5 \\
& 23 & 4 & 0,567 \\
\hline \multirow{3}{*}{ Mar } & 14 & 3 & 0,541 \\
& 5 & 3 & 0,64 \\
& 32 & 2 & 0,170 \\
& 33 & 5 & 0,630 \\
\hline
\end{tabular}


(b) Continued.

\begin{tabular}{|c|c|c|c|}
\hline \multicolumn{4}{|c|}{2006} \\
\hline Month & Abundance & Richness & Simpson \\
\hline \multirow{5}{*}{ May } & 44 & 4 & 0,539 \\
\hline & 188 & 4 & 0,201 \\
\hline & 118 & 4 & 0,373 \\
\hline & 41 & 3 & 0,604 \\
\hline & 75 & 4 & 0,543 \\
\hline \multirow{5}{*}{ Jun } & 21 & 5 & 0,522 \\
\hline & 82 & 3 & 0,361 \\
\hline & 15 & 1 & 0 \\
\hline & 20 & 4 & 0,415 \\
\hline & 0 & 0 & 1 \\
\hline \multirow{5}{*}{ Jul } & 0 & 0 & 1 \\
\hline & 4 & 3 & 0,625 \\
\hline & 0 & 0 & 1 \\
\hline & 2 & 2 & 0,5 \\
\hline & 0 & 0 & 1 \\
\hline
\end{tabular}

many different species of trees, producing different attractive substances when they fall, die, or decay. This may have contributed to the reduced number of specimens collected with the EC trap although the number of species was greater.

The majority of the captured species belong to the Xyleborini tribes, with 13 species, distributed in the genera Xyleborus, Sampsonius, Premnobius, and Theoborus, followed by Corthylini, with the genera Monarthrum and Amphicranus. These species are prevalent in tropical regions, with xylomycetophagous habits, that is, feed on fungi that grow inside the plant. Another tribe found was Cryphalini, with the genera Cryptocarenus and Hypothenemus, also common in tropical regions, with varied eating habits, being considered myelophagous because they feed on pith and buds, phloephagous, feed on the tissues of the phloem, and xylophagous, feed on the xylem $[1,39]$. This was also observed in the work of Abreu [14].

The Xyleborus genus was represented by six species, but Xyleborus volvulus and X. affinis were dominant and found both in flight and on ground. These species are quite common and abundant in primary forest of Amazonas State, according to the work of Abreu [14] and Matias and Abreu [12], and, from what can be seen, they also have outstanding preference for the region of the collections, since there is a large difference between them and the other species, including when compared with those that have the same eating habits.

The species $X$. ferrugineus, despite being regarded as one of the most important and abundant in tropical regions, including being the vector of Ceratocystis fimbriata (Ellis \& Halsted) fungus that causes the death of several plants $[1,40,41]$ presented low abundance, confirming the work carried out by Abreu [8], Abreu and Bandeira [9], Matias and Abreu [12], and Abreu [14]. In contrast, many works carried out in the South, Southeast and Midwest of Brazil show that this species is abundant in those regions $[22,33,34,36,37]$, being considered fairly common in Brazil.
TABle 4: Abundance, richness, and Simpson index of the species collected with five Escolitideo/Curitiba traps from July 2005 to July 2006.

\begin{tabular}{|c|c|c|c|}
\hline \multicolumn{4}{|c|}{2005} \\
\hline Month & Abundance & Richness & Simpson \\
\hline \multirow{5}{*}{ Jul } & 6 & 4 & 0,722 \\
\hline & 2 & 1 & 0 \\
\hline & 3 & 2 & 0,444 \\
\hline & 2 & 1 & 0 \\
\hline & 2 & 1 & 0 \\
\hline \multirow{5}{*}{ Aug } & 11 & 5 & 0,744 \\
\hline & 6 & 4 & 0,667 \\
\hline & 12 & 7 & 0,708 \\
\hline & 4 & 2 & 0,375 \\
\hline & 3 & 3 & 0,667 \\
\hline \multirow{5}{*}{ Sep } & 6 & 3 & 0,667 \\
\hline & 10 & 5 & 0,76 \\
\hline & 10 & 7 & 0,78 \\
\hline & 7 & 3 & 0,571 \\
\hline & 9 & 4 & 0,617 \\
\hline \multirow{5}{*}{ Oct } & 5 & 5 & 0,8 \\
\hline & 10 & 8 & 0,86 \\
\hline & 9 & 6 & 0,741 \\
\hline & 9 & 6 & 0,790 \\
\hline & 1 & 1 & 0 \\
\hline \multirow{5}{*}{ Nov } & 14 & 8 & 0,837 \\
\hline & 11 & 5 & 0,711 \\
\hline & 4 & 3 & 0,625 \\
\hline & 4 & 3 & 0,625 \\
\hline & 5 & 5 & 0,8 \\
\hline \multirow{5}{*}{ Dec } & 5 & 4 & 0,72 \\
\hline & 0 & 0 & 1 \\
\hline & 0 & 0 & 1 \\
\hline & 1 & 1 & 0 \\
\hline & 0 & 0 & 1 \\
\hline
\end{tabular}

(b)

\begin{tabular}{lccc}
\hline \multirow{3}{*}{ Month } & \multicolumn{2}{c}{2006} & \\
\multirow{4}{*}{ Jan } & Abundance & Richness & Simpson \\
\hline & 20 & 6 & 0,64 \\
& 18 & 4 & 0,377 \\
& 10 & 5 & 0,68 \\
& 13 & 2 & 0,142 \\
\multirow{3}{*}{ Mar } & 20 & 5 & 0,545 \\
& 4 & 2 & 0,375 \\
& 5 & 1 & 0 \\
& 9 & 4 & 0,72 \\
& 8 & 4 & 0,667 \\
\hline
\end{tabular}


(b) Continued.

\begin{tabular}{lccc}
\hline \multirow{4}{*}{ Month } & \multicolumn{2}{c}{2006} & \\
\multirow{3}{*}{ May } & Abundance & Richness & Simpson \\
\hline & 19 & 4 & 0,575 \\
& 13 & 8 & 0,731 \\
& 19 & 5 & 0,734 \\
& 15 & 7 & 0,765 \\
Jun & 12 & 6 & 0,658 \\
& 12 & 5 & 0,764 \\
& 12 & 5 & 0,764 \\
& 13 & 3 & 0,486 \\
Jul & 13 & 4 & 0,485 \\
& 27 & 4 & 0,675 \\
\hline & 46 & 3 & 0,565 \\
& 11 & 3 & 0,163 \\
& 38 & 4 & 0,645 \\
& 19 & 7 & 0,636 \\
& & 5 & 0,504 \\
\hline
\end{tabular}

Another very representative genus was the Sampsonius, with five species, including $S$. dampfi. The species in this genus also feed on fungi that grow in the host. As females are unable to construct an entrance tunnel in the plant, they look for recently constructed galleries of Xyleborus, appropriate for their bodies. After entering, they wait until the tunnels are extended, cleaned, and after that they expel the lodgers [1].

Many Scolytinae are attracted by resin-oils, terpene hydrocarbons or alcohols and other substances emanating from the vascular tissues of newly felled trees, decayed and still with high levels of humidity $[3,4]$. In accordance with Hulcr et al. [35], ambrosia beetles are strongly attracted by hosts that liberate high levels of alcohol.

This work reinforces the theory that ambrosia beetles are common in tropical forests, because these environments present favorable climatic conditions for the development of these insects, as well as their fungal symbionts. Studies carried out by Hulcr et al. [35, 42] in forests of Thailand and Papua New Guinea confirmed this theory.

\section{Conclusions}

The capture of Scolytinae in primary forest of Central Amazon shows a low diversity of these insects and the existence of two predominant species in the region. It also shows that many species, in addition to flying, also have activities on forest ground. In this area there are many lignocellulosic materials as trunks and branches of trees, where they can cultivate the fungi they feed on.

The majority of the insects collected in the studied area have no correlation with the temperature and rainfall.

\section{Acknowledgments}

The authors would like to thank the doctoral student Fabricio Baccaro of the postgraduate programme at INPA, for the help with the statistical analyses and also the laboratory technicians Frank Antonio de Oliveira Campos and Janio da Costa Santos for their help in field collections.

\section{References}

[1] S. L. Wood, The Bark and Ambrosia Beetles of North and Central America (Coleoptera: Scolytidae), A Taxonomic Monograph, Great Basin Naturalist Memoirs, no. 6, 1982.

[2] R. A. Beaver, "Bark and ambrosia beetles in tropical forests," in Proceedings of the Symposium on Forest Pests and Diseases in Southeast Asia, vol. 2, pp. 133-149, Biotrop Seameo Regional Center for Tropical Biology, Biotrop Special Publication, Bogor, Indonesia, 1977.

[3] J. A. Gagne and W. H. Kearby, "Host selection by Xyleborus celsus (Coleoptera: Scolytidae) in Missouri," The Canadian Entomologist, vol. 110, no. 10, pp. 1009-1013, 1978.

[4] H. A. Moeck, "Ethanol induces attack on trees of spruce beetles, Dendroctonus rufipennis (Coleoptera: Scolitydae)," Canadian Entomologist, vol. 113, pp. 939-942, 1981.

[5] G. Déon, Manual de Preservação das Madeiras em Clima Tropical, Tradução Antônio Carlos Mascarenhas. Série Técnica 3, Escola Politécnica da Universidade Federal da Bahia, Salvador, Brazil, 1989.

[6] A. C. B. Mendes, Insetos Associados ao Cacaueiro na Amazônia (Reconhecimento e Controle), CEPLAC/DEPEA, Belém, Brazil, 1978.

[7] R. L. S. Abreu and C. R. R. C Dietrich, "Ocorrência de besouros (Insecta: Coleoptera) em madeiras úmidas," in 3rd Encontro Brasileiro de Madeira e em Estruturas de Madeira, pp. 227-237, São Paulo, Brazil, 1989.

[8] R .L. S. Abreu, "Estudos sobre a ocorrência de Scolytidae e Platypodidae em madeiras da Amazônia," Acta Amazonica, vol. 22, no. 3, pp. 413-420, 1992.

[9] R. L. S. Abreu and A. G. Bandeira, "Besouros xilomicetófagos economicamente importantes da região de Balbina, Estado do Amazonas," Revista Árvore, vol. 16, no. 3, pp. 346-356, 1992.

[10] M. G. V. Barbosa, Contribuição ao conhecimento da Coleopterofauna visitante de cupuaçu (Theobroma grandiflorum [Willdenow ex Sprengel]) Schumman em um bairro de Manaus, Amazonas, Dissertação de Mestrado, INPA/FUA, Manaus, Brazil, 1994.

[11] O. T. Dall'Oglio and O. Peres Filho, "Levantamento e flutuação populacional de coleobrocas em plantios homogêneos de seringueira em Itiquira-MT, Brasil," Scienta Forestalis, vol. 51, pp. $45-58,1997$.

[12] E. O. Matias and R. L. S. Abreu, "Estudo da sucessão de Coleoptera (besouros) e Isoptera (cupins) em madeiras de Presidente Figueiredo, Amazonas," in VIII Jornada de Iniciação Científica do PIBIC/INPA, pp. 52-55, Manaus, Brazil, 1999.

[13] N. D. Penny and J. R. Arias, Insects of an Amazon Forest, Columbia University Press, New York, NY, USA, 1982.

[14] R. L. S. Abreu, "Análise das principais espécies de Scolytidae coletadas em floresta primária no Estado do Amazonas," Anais da Sociedade Entomológica do Brasil, vol. 26, no. 3, pp. 527535, 1997.

[15] R. L. S. Abreu, C. R. V. Fonseca, J. C. H. Guerrero, and E. V. C. M. Paula, "Preferência de vôo de nove espécies da família Scolytidae (Insecta: Coleoptera) na Amazônia Central,” Acta Amazonica, vol. 31, no. 1, pp. 61-68, 2001.

[16] H. O. R. Schubart and L. Beck, "Zur Coelopterenfauna amazonischer Boden," Amazoniana, vol. 1, no. 4, pp. 311-322, 1968. 
[17] J. W. Morais, Abundância e distribuição vertical de Arthropoda do solo numa floresta primária não inundada, Dissertação de Mestrado, Instituto Nacional de Pesquisas da Amazônia/ Fundação Universidade do Amazonas, 1985.

[18] J. W. Morais, Abundância, distritribuição vertical e fenologia da fauna de Arthropoda de uma região de água mista, próxima de Manaus/AM, Ph.D. thesis, Tese de Doutorado, Universidade de São Paulo/Escola superior de Agricultura Luiz de Queiroz, 1995.

[19] J. M. G. Rodrigues, "Abundância e distribuição vertical de coleópteros de solo em capoeira de terra firme na Região de Manaus-Am, Brasil," Acta Amazonica, vol. 22, no. 3, pp. 323333, 1992.

[20] M. N. G. Ribeiro, "Aspectos climatológicos de Manaus," Acta Amazonica, vol. 6, no. 2, pp. 229-233, 1976.

[21] G. Ranzani, "Identificação e caracterização de alguns solos da Estação Experimental da Silvicultura Tropical do INPA," Acta Amazonica, vol. 10, no. 1, pp. 7-14, 1980.

[22] A. F. Carrano-Moreira, Análise faunística de Scolytidae em comunidades florestais do Estado do Paraná, Dissertação de Mestrado, UFRPE, Recife, Brazil, 1985.

[23] D. E. Bright, "Scolytidae (Coleoptera) from Cocos Islands, Costa Rica, with description one new species," Coleoprist Bulletin, vol. 36, no. 1, pp. 127-130, 1982.

[24] D. E. Bright, "Studies in Xyleborini 2. Review of the genus Sampsonius Eggers (Coleoptera: Scolytidae)," Studies on Neotropical Fauna and Environment, vol. 26, no. 1, pp. 11-28, 1991.

[25] D. E. Bright and S. B. Peck, "Scolytidae from the Galápagos Islands, Ecuador, with descriptions of four new species, new distribution records, and a key to species (Coleoptera: Scolytidae)," Koleopterologische Rundschau, vol. 68, pp. 233-252, 1998.

[26] S. L. Wood, "Los Scolytidae de Costa Rica: clave de géneros y de la subfamilia Hylesinae (Coleoptera)," Revista de Biologia Tropical, vol. 39, no. 1, pp. 125-148, 1991.

[27] S. L. Wood, "Scolytidae (Coleoptera) de Costa Rica II. Clave para ala subfamília Scolytinae, tribus: Scolytini, Ctenophorini, Micracini, Ipini, Dryocoetini, Xuleborini y Cryphalini," Revista de Biologia Tropical, vol. 39, no. 2, pp. 279-306, 1991.

[28] S. L. Wood, Bark and Ambrosia Beetles of South America (Coleoptera: Scolytidae), Brigham Young University, Provo, Utah, USA, 2007.

[29] S. Silveira Neto, O. Nakano, D. Berbin, and N. A. Villa Nova, Manual de Ecologia dos Insetos, Agronômica Ceres, São Paulo, Brazil, 1976.

[30] F. S. Bodenheimer, Precis d' Ecologieanimale, Payot, Paris, France, 1955.

[31] J. H. Zar, Biostatistical Analysis, Prenticehall, Englewood Cliffs, NJ, USA, 1974.

[32] J. C. Moser and T. R. Dell, "Predictors of Southern Pine Beetle activity," Forest Science, vol. 25, pp. 217-222, 1979.

[33] A. Dorval, Levantamento populacional de coleópteros com armadilhas etanólicas em plantios de Eucalyptus spp. e em uma área com vegetação de cerrado no município de Cuiabá, estado de Mato Grosso, Dissertação de Mestrado, Universidade Federal do Paraná, 2002.

[34] C. A. H. Flechtmann, A. L. T. Ottati, and C. W. Berisford, "Ambrosia and bark beetles (Scolytidae: Coleoptera) in pine and eucalypt stands in southern Brazil," Forest Ecology and Management, vol. 142, no. 1-3, pp. 183-191, 2001.

[35] J. Hulcr, R. A. Beaver, W. Puranasakul, S. A. Dole, and S. Sonthichai, "A comparison of bark and ambrosia beetle communities in two forest types in northern Thailand (Coleoptera:
Curculionidae: Scolytinae and Platypodinae)," Environmental Entomology, vol. 37, no. 6, pp. 1461-1470, 2008.

[36] E. N. Marques, Scolytidae e Platypodidae em Pinus taeda, Dissertação de Mestrado, Universidade Federal do Paraná, 1984.

[37] E. N. Marques, Índices faunísticos e grau de infestação por Scolytidae em madeira de Pinus spp, Ph.D. thesis, Tese de Doutourado, Universidade Federal do Paraná, 1989.

[38] C. A. H. Flechtmann, Altura de vôo de Scolytidae em reflorestamento com pinheiros tropicais na região de Agudos, Estado de São Paulo, Dissertação de Mestrado, ESALQ/USP, Piracicaba, Brazil, 1988.

[39] T. H. Atkinson, "Los generos de la familia Scolitydae (Coleoptera en Mexico. Resumen de su taxonomía y biología," in Memoria de Los Simposia Nacionales de Parasitologia Florestal II y III, vol. 46, Secretaria de Agricultura y Recursos Hidraulicos, Mexico, D.F., México, 1985.

[40] F. G. Browne, "Notes on Xyleborus ferrugineus (F)," in Proceedings of the 5th Report of the West Africa Timber Borer Research Unit, pp. 47-55, 1961-1962.

[41] R. A. Beaver, "Biological studies of Brazilian Scolitydae and Platypodidae (Coleoptera). V. The tribe Xyleborini," Zeitschrift für Angewandte Entomologie, vol. 80, no. 1-4, pp. 15-30, 1976.

[42] J. Hulcr, V. Novotny, B. A. Maurer, and A. I. Cognato, "Low beta diversity of ambrosia beetles (Coleoptera: Curculionidae: Scolytinae and Platypodinae) in lowland rainforests of Papua New Guinea," Oikos, vol. 117, no. 2, pp. 214-222, 2008. 

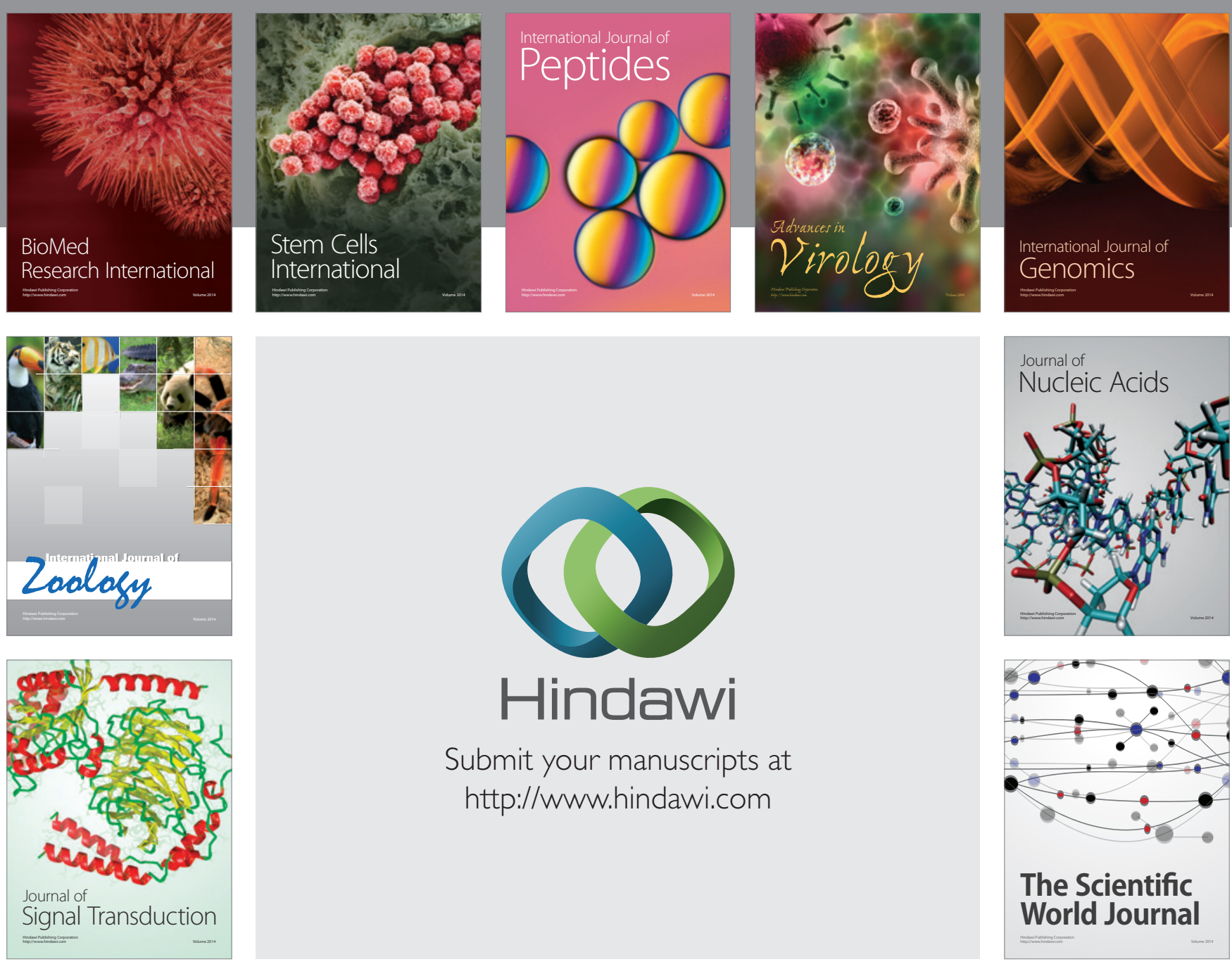

Submit your manuscripts at

http://www.hindawi.com
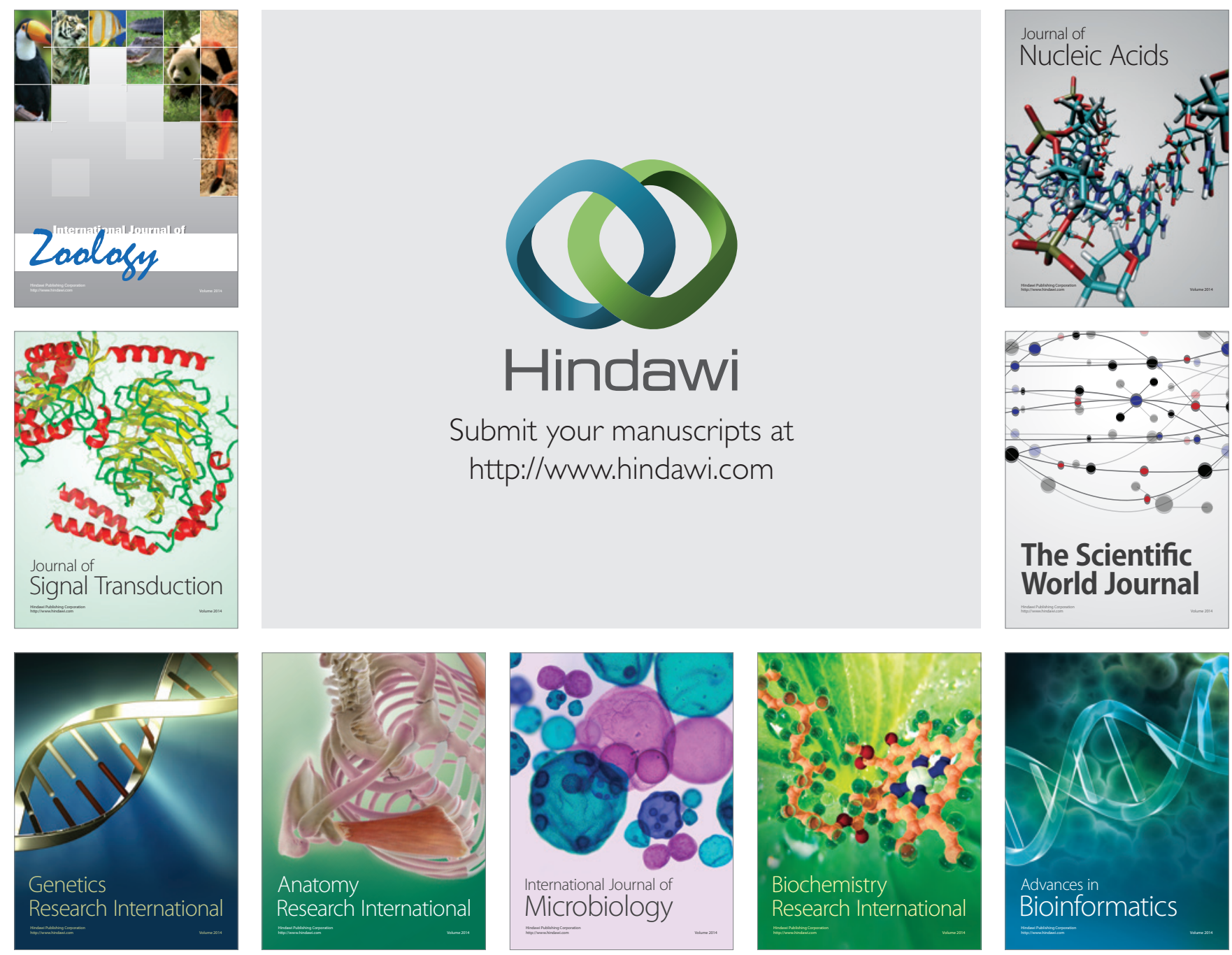

The Scientific World Journal
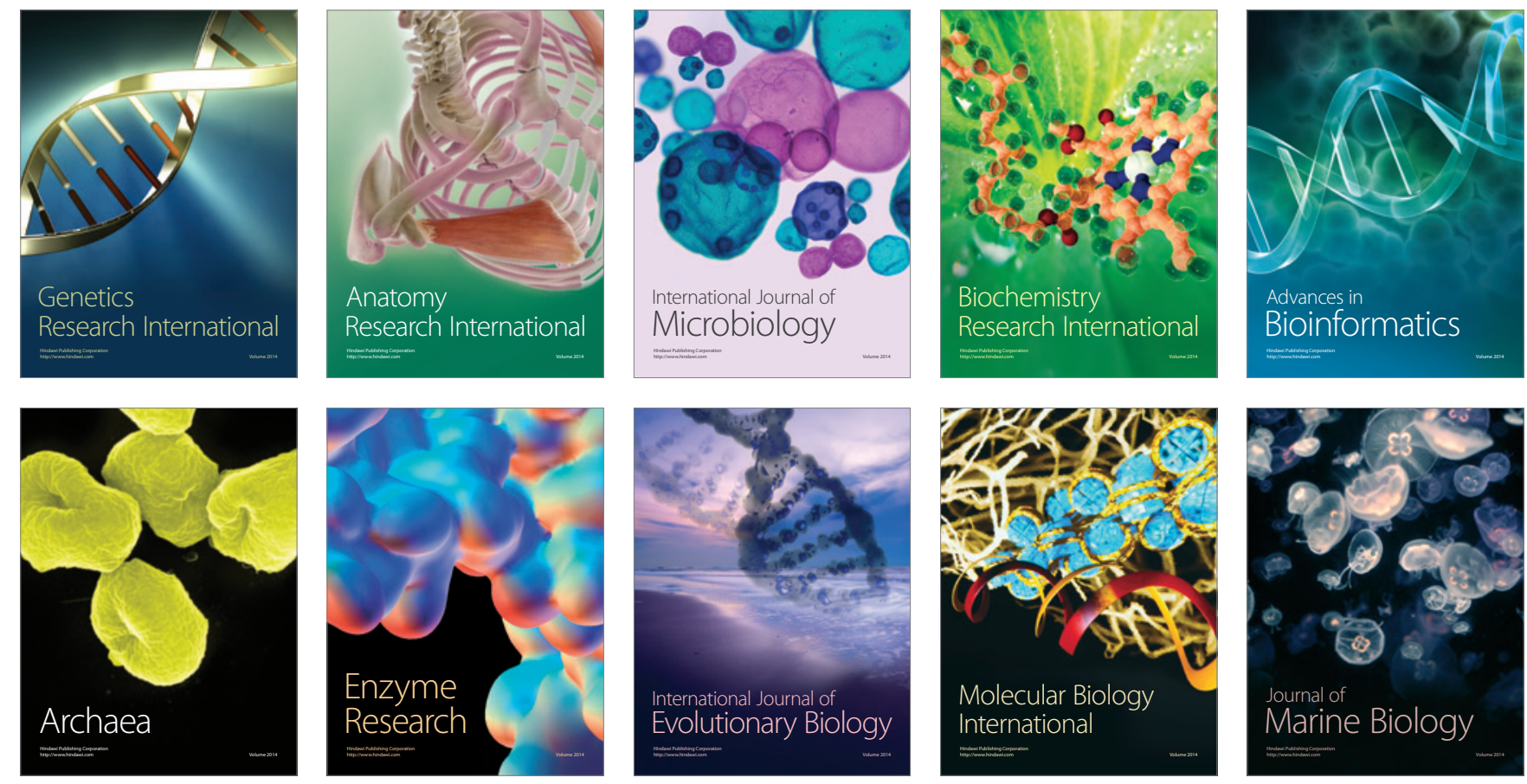